\title{
PENGARUH LITERASI KEUANGAN DAN GAYA HIDUP TERHADAP PERILAKU KEUANGAN KARYAWAN PERTAMBANGAN BATU BARA DIKABUPATEN SAROLANGUN (PT. MANDIANGIN BARA SINERGI)
}

\author{
Sri Hardiyanti \\ Direktur Subkontraktor PT. MBP Sarolangun, Jambi \\ Srihardiyanti67@yahoo.com
}

\begin{abstract}
Abstrak
Tujuan penelitian ini adalah untuk mengetahui Pengaruh Literasi Keuangan dan Gaya Hidup Terhadap Perilaku Keuangan Karyawan Pertambangan Batu Bara Dikabupaten Sarolangun PT. Mandiangin Bara Sinergi (PT. MBS). Pengumpulan data dilakukan dengan survei menggunakan kuesioner yang diberikan kepada 55 responden di perusahaan Pertambangan Batu Bara PT. MBS Di Kabupaten Sarolangun. Alat analisis yang digunakan adalah Smart PLS 3. Hasil penelitian ini meneunjuk kan bahwa Literasi keuangan secara parsial memiliki pengaruh yang signifikan terhadap perilaku keuangan, Gaya hidup secara parsial memiliki pengaruh yang signifikan terhadap perilaku keuangan, Literasi keuangan dan gaya hidup secara simultan mempunyai pengaruh yang signifikan terhadap perilaku keuangan dan kesimpulan dari penelitian ini adalah bahwa literasi keuangan dan gaya hidup sangat berpengaruh terhadap prilaku keuangan Karyawan Pertambangan Batu Bara PT. MBS.
\end{abstract}

Kata Kunci: Literasi Keuangan, Gaya Hidup, Prilaku Keuangan

\begin{abstract}
The purpose of this study was to determine the effect of financial literacy and lifestyle on the financial behavior of coal mining employees in the Sarolangun district PT. Mandiangin Bara Sinergi (PT. MBS). Data collection was carried out by survey using a questionnaire given to 55 respondents in the Coal Mining company PT. SBM In Sarolangun District. The analytical tool used is Smart PLS 3.The results of this study indicate that financial literacy partially has a significant effect on financial behavior, lifestyle partially has a significant influence on financial behavior, financial literacy and lifestyle simultaneously have a significant effect. on financial behavior and the conclusion of this study is that financial literacy and lifestyle are very influential on the financial behavior of Coal Mining Employees of PT. MBS.
\end{abstract}

Keywords: Financial Literacy, Lifestyle, Financial Behavior

\section{PENDAHULUAN}

Pada era globalisasi sekarang ini sangat dibutuhkan dan diperlukan pengetahuan tentang pengelolaan keuangan dengan baik dan cermat. Di Indonesia, tingkat pengetahuan keuangan atau financial literation dari masyarakat Indonesia dapat dikatakan masih jauh tertinggal dari Singapura, Malaysia, dan Thailand. Dapat dilihat dari gambar dibawah ini bahwa singapore menduduki tingkat pertama yaitu $96 \%$ dan dilanjutkan oleh Malaysia sebanyak $81 \%$ kemudian Thailand sebanyak 78\% dan Indonesia 38\% dan dapat dilihat bahwa Indonesia jauh dari ketiga negara tersebut dalam pengetahuan tentang penggelolaan keuangan atau financial literation.((Suryanto.(2017)) 
Dalam rangka mencapai kesejahteraan keuangan, seseorang perlu memiliki pengetahuan, sikap, dan implementasi keuangan pribadi yang sehat. Sejauh mana pengetahuan, sikap dan implementasi seseorang dalam mengelola keuangan, erat kaitannya dengan literasi keuangan. Penggelolaan keuangan yang tepat dan ditunjang dengan literasi keuangan yang baik maka taraf hidup masyarakat diharapkan akan meningkat, bagaimanapun tingginya tingkat penghasilan seseorang tapi tanpa penggelolaan keuangan yang tepat, keamanan finansial pasti akan sulit tercapai dengan perubahan gaya hidup yang dialami oleh masyarakat, memberikan pengaruh pada perilaku masyarakat khususnya perilaku keuangan para pekerja. Dengan meningkatnya gaya hidup seseorang, akan menimbulkan masalah dalam pengelolaan keuangan. Idealnya, faktor literasi keuangan dan gaya hidup bisa mempengaruhi terhadap perilaku keuangan seseorang dalam mengelola keuangan. Pengetahuan tentang keuangan akan membentuk perilaku keuangan seseorang dengan baik. Sehingga dapat dikatakan semakin tinggi literasi keuangan seseorang maka semakin baik perilaku keuangannya begitupun sebaliknya. Sedangkan gaya hidup mempunyai dampak yang positif dan negatif. Jika seseorang dengan literasi yang tinggi dan gaya hidup yang sesuai dengan keadaan pendapatnya maka seseorang tersebut akan mampu dalam mengeola keuangannya.

Industri pertambangan merupakan industri yang berkonsentrasi pada pengeksploitasi hasil bumi yang kemudian diolah untuk memperoleh nilai, kemudian dijual untuk memperoleh laba yang diinginkan oleh manajemen perusahaan. Perusahaan pertambangan cenderung diminati oleh para investor dalam negeri maupun luar negeri untuk mendirikan perusahaan guna mengambil aset Negara Indonesia kemudian memberikan persentase keuntungan pembagian kepada pemerintah pusat, namun semua itu perlu diperhatikan bahwa pertambangan hasil bumi ini adalah sumber daya alam (SDA) yang tidak dapat diperbaharui. oleh karena itu dalam jangka waktu panjang hasil olahan dalam bumi ini akan habis serta akan menggangu perkembangan perekonomian di Indonesia sendiri. Serta akan adanya penggangguran jumlah besar yaitu terhadap karyawan yang berkontribusi diperusahaan pertambangan tersebut. pertambangan sejauh ini belum menunjukan akan adanya indikasi penguatan, terlebih lagi dengan tidak adanya stimulus baik stimulus dari pemerintahan maupun pasar. Sektor pertambangan yang didominasi oleh batu bara belum menujukan akan adanya peningkatan harga komoditas batu bara, harga batu bara yang terus menurun membuat perusahaan tambang batu bara terus merugi. Bisnis batu bara pada tahun 2019 masih ditandai dengan penurunan harga yang cukup signifikan dimulai dari akhir tahun 2019. Turun nya harga batu bara ini menyebabkan eskpor batu bara indonesia menjadi menurun. Rendahnya harga jual batu bara tidak dapat menutupi biaya operasional perusahaan, akibat dari biaya operasional yang tinggi yang tidak dapat disesuaikan dengan harga jual batu bara sehingga banyak industri batu bara yang mendekati kerugian, bahkan tidak sedikit pula yang sudah tidak mampu bertahan sehingga mereka menutup usahanya. ini berdampak kepada karyawan yang berkerja diperusahaan pertambangan batu bara tersebut.

Salah satunya perusahaan pertambangan Batu Bara yang berada di Sarolangun memiliki banyak karyawan, apabila terjadinya penutupan lahan tambang diakibatkan oleh 
habisnya hasil bumi atau sumber daya alam (SDA), maka karyawan yang berkerja akan menanggung akibatnya. Maka dengan ini para karyawan khususnya pertambangan batu bara ini harus mengetahui bagaimana cara mengatur keuangan, dalam hal ini tidak semua karyawan tau tentang keuangan seperti literasi keuangan dan gaya hidup terhadap perilaku keuangan. PT.MBS di Kabupaten Sarolangun terdapat 122 karyawan, jumlah total dari karyawan tersebut dimana terdapat karyawan kantor pusat sebanyak 20 orang karyawan, karyawan kantor lapangan sebanyak 18 orang, karyawan lapangan sebanyak 84 orang. Menurut data yang diperoleh ditemukan adanya penurunan harga batu bara secara signifikan sehingga meyebabkan perusahaan mengambil keputusan untuk mengurangi gaji karyawan sebanyak $30 \%$.

Kondisi tersebut sangat kompleks karena sebagian besar karyawan pertambangan batu bara (PT. MBS) menghadapi masalah seperti melakukan pembayaran kewajiban yang didebet setiap bulannya, keperluan keluarga, dan keperluan yang sifatnya tak terduga, serta gaya hidup terbiasa dengan pola konsumtif sehingga menjadi sangat boros. Ditambah lagi dengan kurangnya pengetahuan mengenai keuangan itu sendiri. Dalam hal ini sebagian karyawan Pertambangan Batu Bara (PT. MBS) mendapatkan masalah dari kondisi tersebut dikarnakan disaat Pademik COVID-19 Perusahaan Pertambagan Batu Bara banyak mendapatkan masalah karna turunya Harga Batu Bara yang sangat signifikan dan ini membuat Perusahaan Pertambangan Batu Bara memberikan kebijakan sebagian karyawan dirumahkan dan sebagiannya pengurangan gaji sebanyak 30\% kebijakan ini dibuat agar perusahaan dapat bertahan disaat Pademik COVID-19 ini.

Berdasarkan latar belakang yang telah dikemukakan diatas maka menimbulkan kertertarikan peneliti untuk mengangkat tema utama yaitu : "Pengaruh Literasi Keuangan dan Gaya Hidup Terhadap Perilaku Keuangan Karyawan Pertambangan Batu Bara Dikabupaten Sarolangun ( PT. MBS )”.

\section{KAJIAN PUSTAKA}

\section{Literasi Keuangan}

Perkembangan pada zaman ini, setiap individu dituntut untuk memiliki pengetahuan tentang mengelola keuangan agar dapat efektif demi kesejahteraan finansial. Pengetahuan mengenai pengelolaan keuangan merupakan dasar bagi setiap individu untuk membantu membuat sebuah keputusan keuangannya, khususnya keputusan untuk menggelola keuangannya. Literasi keuangan adalah "Proses Pembuatan Makna" dimana indivindu menggunakan kombinasi keterampilan, sumber daya, dan pengetahuan kontekstual untuk memproses informasi dan membuat keputusan dengan pengetahuan tentang konsekuensi keuangan dari keputusan tersebut (Upadana \& Herawati, 2020).

\section{Gaya Hidup}

Gaya hidup adalah menunjukkan bagaimana orang hidup, bagaimana membelanjakan uang nya dan bagaimana mengalokasikan waktu. Sehingga dapat disimpulkan bahwa gaya hidup adalah pola hidup seseorang yang dinyatakan dalam kegiatan, minat, dan pendapatnya dalam membelanjakan uangnya dan bagaimana mengalokasikan waktu. Gaya hidup mencerminkan pola konsumtif yang menggambarkan 
pilihan seseorang untuk bagaimana ia mempergunakan waktu dan uangnya. Jadi definisi di atas dapat disimpulkan bahwa gaya hidup lebih menggambarkan perilaku seseorang, yaitu bagaimana ia hidup, menggunakan uangnya dan memanfaatkan waktu yang dimilikinya (Rina Rahayu, 2015).

\section{Prilaku Keuangan}

Perilaku keuangan merupakan pola kebiasaan dan tingkah laku seseorang ketika mengatur keuangan pribadinya. Setiap individu akan selalu dihadapkan oleh masalah seberapa besar uang yang diterima dan dikeluarkan. Dalam beberapa kasus terdapat masalah uang yang diterima atau dihasilkan seseorang lebih kecil dibandingkan pengeluarannya hal ini dikarenakan bagaimana perilaku keuangan individu tersebut. Individu dengan perilaku keuangan baik cenderung lebih bijak dan cerdas dalam menggunakan dana atau sumber daya yang dimikinya, seperti mengkontrol belanja, mencatat pengeluaran dan berinvestasi. Perilaku keuangan dan keputusan investasi adalah dua hal yang saling berkaitan (Suryanto, 2017).

\section{Kerangka Pemikiran}

Penelitian ini meneliti tentang Pengaruh Literasi Keuangan Dan Gaya HidupTerhadap Prilaku Keuangan Karyawan Pertambangan Batu Bara Di Kabupaten Sarolangun (PT. MBS) Untuk lebih jelasnya, dapat dilihat pada gambar berikut :

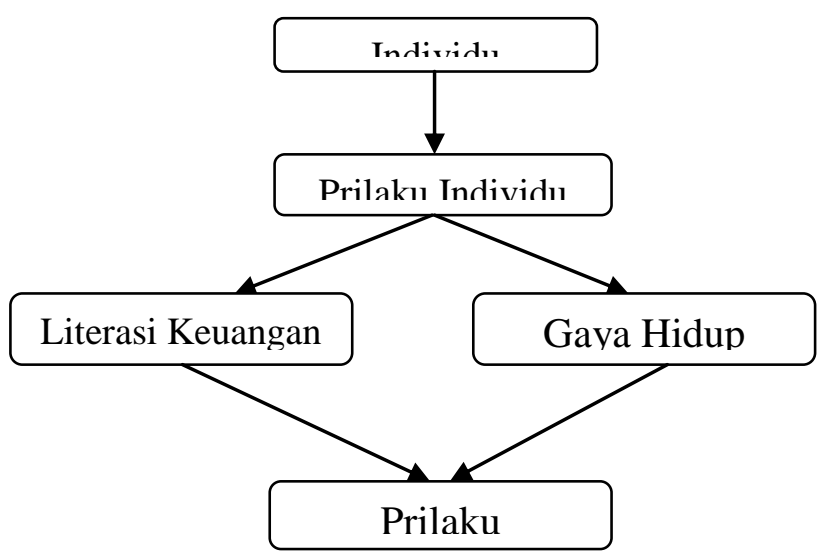

\section{Hipotesis}

'Hipotesis penelitian menjadi sebagai berikut :

$\mathrm{H}_{1}=$ literasi keuangan berpengaruh signifikan terhadap perilaku keuangan karyawan pertambangan batu bara Sarolangun di PT.MBS.

$\mathrm{H}_{2}$ = gaya hidup berpengaruh signifikan terhadap perilaku keuangan karyawan pertambangan batu bara Sarolangun di PT.MBS.

$\mathrm{H}_{3}=$ literasi keuangan, Gaya Hidup, secara simultan berpengaruh signifikan terhadap perilaku keuangan karyawan pertambangan batu bara Sarolangun di PT.MBS.

\section{METODE PENELITIAN}

\section{Populasi Dan Sampel}

Populasi dalam penelitian ini adalah Karyawan Pertambangan Batu Bara yang berada di Kabupaten Sarolangun di PT. MBS. Jumlah populasi dalam penelitian ini adalah 
122 orang. Teknik pengambilan sampel dalam penelitian ini menggunakan rumus slovin yaitu menggunakan metode purposive sampling. Sampel yang digunakan adalah yaitu penarikan sampel yang didasarkan pada kriteria penelitian. Dalam penelitian ini kriteria sample yang dipakai adalah :

1. Karyawan yang bekerja pada PT.MBS.

2. Karyawan PT.MBS yang bersedia menjadi responden

3. Karyawan PT.MBS yang tingkat pendidikannya dari SMA kebawah

4. Karyawan PT.MBS yang berumur 25 hingga 40 tahun.

5. Karyawan PT.MBS yang sudah bekerja $\geq 6$ bulan

Yaitu dimana rumus Slovin adalah sebagai berikut :

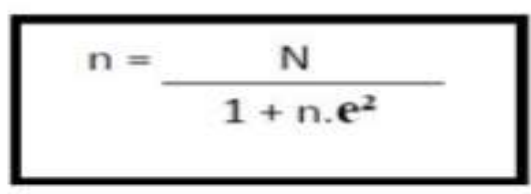

Keterangan :

$\mathrm{n}=$ Ukuran Sampel/jumlah responden

$\mathrm{N}=$ Ukuran populasi

$\mathrm{e}=$ Presentase kelonggaran ketelitian kesalahan pengambilan sampel yang masih bisa ditolerir:

$\mathrm{e}=0,1$

Maka untuk mengetahui sampel peneletian dengan perhitungan sebagai berikut :

$$
\begin{aligned}
& \mathbf{n}=\frac{122}{1+122(0,1)^{2}} \\
& \mathbf{n}=\frac{122}{1+122(0,01)} \\
& \mathbf{n}=\frac{122}{2.22} \quad \mathbf{n}=54,9
\end{aligned}
$$

Disesuaikan oleh peneliti menjadi 55 responden, jadi sampel berjumlah 55 responden dengan kriteria inklusi.

\section{Teknik Analisis Data}

Skala pengukuran yang dipilih oleh peneliti berkaitan erat dengan metode analisis data yang digunakan digunakan oleh peneliti untuk menganalisis data yang telah dikumpulkan termasuk pengujiannya.Teknik analisis data yang digunakan adalah analisis metode Partial Least Square (PLS).

\section{Partial Least Square (PLS)}

Analisis data dilakukan dengan metode Partial Least Square (PLS). Analisis PLS adalah analisis yang menentukan hubungan sebab akibat (Ghozali, 2016). Data yang digunakan dalam PLS tidak harus memenuhi persyaratan asumsi normatif data, dengan demikian PLS memberiakan kelonggaran pada data yang tidak berkontribu normal. Tujuan analisis PLS adalah membantu peneliti untuk tujuan prediksi (Ghozali, 2016). 


\section{Uji Goodness Of Fit Outer Model} Validitas

Validitas merupakan suatau ukuran yang menunjukkan kevalidan atau kesahihan suatu nstrumen penelitian. Pengujian validitas itu mengacu pada sejauh mana suatu instrumen dalam menjalankan fungsi. Instrumen dikatakan valid juka instrumen tersebut dapat digunakan untuk mengukur apa yang hendak diukur. Untuk hasil uji validitas tidak berlaku secara universal, artinya bahwa suatu instrumen dapat memiliki nilai valid yang tinggi pada saat tertentu dan tempat tertentu, akan tetapi menjadi tidak valid untuk waktu yang berbeda atau pada tempat yang berbeda (Slamet, 2020). Untuk perhitungan uji validitas dari sebuah instrumen dapat menggunakan rumus korelasi product moment atau dikenal juga dengan korelasi pearson. Adapun rumusnya adalah sebagai berikut :

\section{Reliabilitas}

$$
\mathrm{r}=\frac{N \cdot \sum x y-\left(\sum x\right)\left(\sum y\right)}{\left.\sqrt{\left\{N \cdot \sum x^{2}\right.}-\left(\sum x\right)^{2}\right\}\left\{N \cdot \sum y^{2}-\left(\sum x\right)^{2}\right\}}
$$

Uji reliabilitas adalah ketetapan alat tersebut dalam mengukur apa yang di ukurnya. Artinya kapanpun alat ukur tersebut digunakan akan memberikan hasil ukur yang sama (Slamet riyadi, 2020). Pengujian reliabilitas instrumen dapat dilakukan secara eksternal maupun internal. Secara eksternal pengujian dapat dilakukan dengan test-retest (stability), equivalent dan gabungan keduanya. Secara internal reliabilitas instrument dapat diuji dengan menganalisis konsistensi butir-butir yang ada pada instrument dengan teknik tertentu. Untuk pengujian reliabilitas dapat mengacu pada nilai Cronbach Alpha $(\alpha)$ dimana suatu konstruk atau variabel dinyatakan reliabel apabila memiliki Cronbach Alpha $(\alpha)>0,7$. Rumus uji reliabilitas adalah sebagai berikut :

$$
\mathrm{r}=\left(\frac{k}{(k-1)}\right)\left(1-\frac{\sum \sigma b^{2}}{\sigma t^{2}}\right)
$$

\section{outer model atau measurement model}

Terdapat tiga kriteria dalam menggunakan SmartPLS untuk menilai outer model, yaitu a convergent validity, b discriminant validity, dan c composite reliability. Convergent validity dari model pengukuran dengan refleksif indikator, dinilai berdasarkan korelasi antara item scorecomponent score dengan construct score yang dihitung dengan PLS. Ukuran refleksif individual dikatakan tinggi jika nilai berkorelasi lebih dari 0,7 dengan konstruk yang ingin diukur, untuk penelitian tahap awal dari pengembangan skala pengukuran, nilai loading yang berkisar antara 0,50 sampai 0,60 dianggap (Ghozali, 2016)

\section{Pengukuran Inner Model}

Pengujian inner model atau structual model dilakukan untuk melihat hubungan antar variabel laten, nilai signifikan dan $R$-square dari model penelitian. Structural model dievaluasi dengan menggunakan $R$-square untuk konstruk dependen dan uji t serta signifikan dari koefisien parameter jalur struktural. Dalam menilai model dengan PLS dimulai dengan melihat $R$-square untuk setiap variabel laten depeden. Perubahan nilai $R$ square dapat digunakan untuk menilai pengaruh variabel laten independen tertentu terhadap variaebl laten depeden apakah mempunyai pengaruh substantive (Ghozali, 2016). 


\section{Mengkonstruksi Diagram Jalur}

Fungsi utama dari membangun diagram jalur adalah untuk memvisualisasikan hubungan antaran indikator dengan konstraknya serta antara konstrak yang akan mempermudah peneliti untuk melihat model secara keseluruhan (Ghozali, 2016).

\section{Estimasi}

Nilai estimasi koefisien jalur antara konstruk harus memiliki nilai yang signifikan.

Signifikan hubungan dapat diperoleh dengan prosedur bootsrapping, nilai yang dihasilkan berupa nilai $T$ stasistic yang kemudian dibandingkan dengan t tabel. apakah nilai t stasistik $>\mathrm{t}$ tabel maka nilai estimasi koefisien jalur tersebut signifikan.

\section{HASIL DAN PEMBAHASAN}

\section{Analisis Data}

\section{outer model atau measurement model}

Program Microsoft Excel digunakan untuk menginput dan menghitung data untuk masing-masing Indikator pada penelitian ini menggunakan Selanjutnya software Smart $P L S$ versi 3 digunakan untuk melakukan penginputan dan pernitungan untuk masingmasing indikator. Hasil konstruksi model awal penelitian dengan menggunakan Smart PLS terlihat pada gambar berikut:

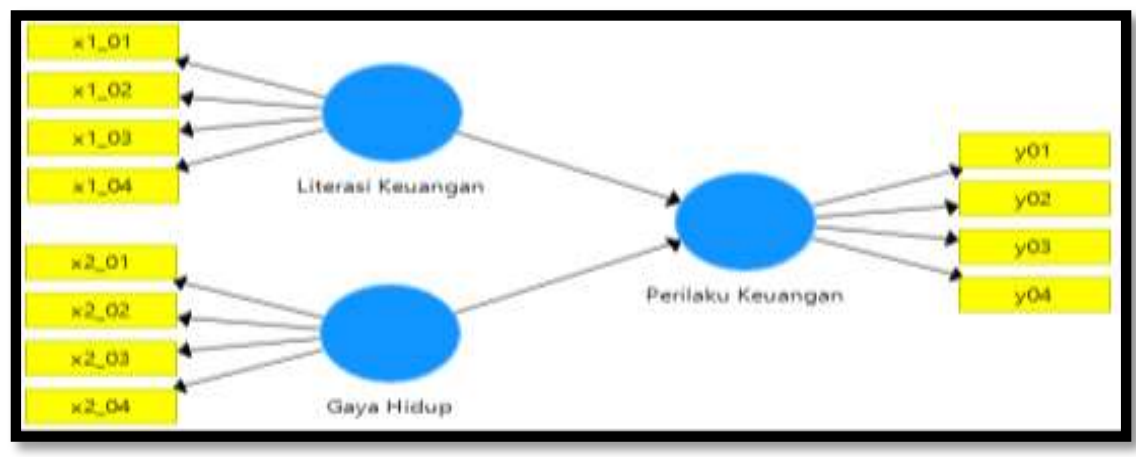

Hasil perhitungan model awal penelitian dengan, menggunakan software Smart PLS 3 terlihat pada gambar berikut:

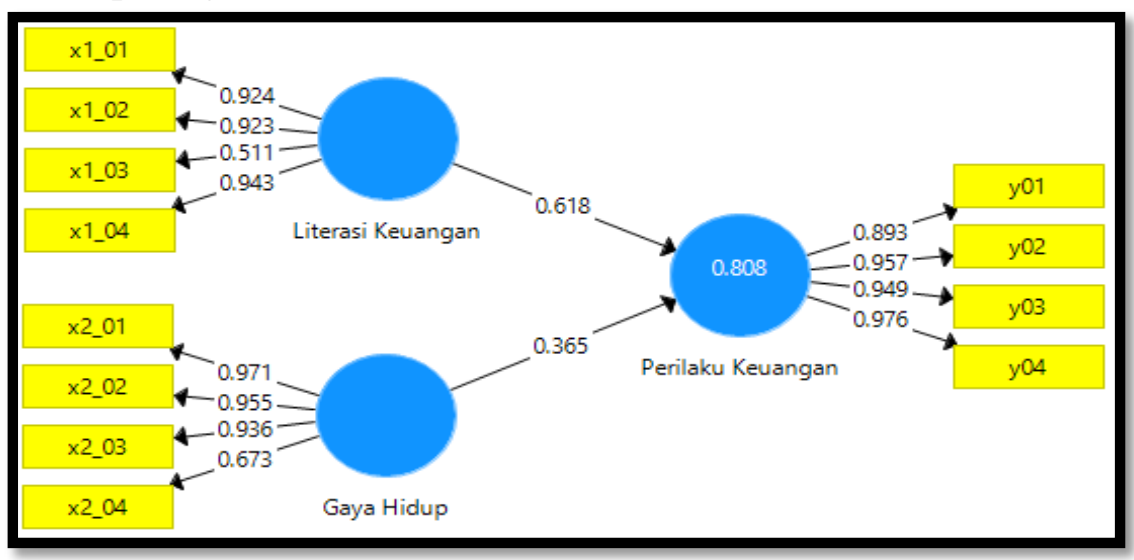

Hasil Perhitungan Model Awal Penelitian

Pengujian discriminant validity dilakukan untuk membuktikan suatu indicator pada suatu konstruk akan mempunyai loading factor terbesar pada konstruk yang dibentuknya 
dari pada loading factor dengan konstruk yang lain.

\section{Uji Inner Model}

\section{Uji Validitas}

Pengujian validitas dalam penelitian ini dapat dilihat dari uji convergen validity. hasil output pengujian validitas dalam penelitian ini dapat dilihat di bawah ini :

\begin{tabular}{|c|c|c|c|}
\hline No Pertanyaan & X1 (Literasi Keuangan) & X2 (Gaya Hidup) & Y (Prilaku Keuangan) \\
\hline X1_01 & $\mathbf{0 , 9 2 4}$ & & \\
\hline X1_02 & $\mathbf{0 , 9 2 3}$ & & \\
\hline X1_03 & $\mathbf{0 , 5 1 1}$ & & \\
\hline X1_04 & $\mathbf{0 , 9 4 3}$ & & \\
\hline X2_01 & & $\mathbf{0 , 9 7 1}$ & \\
\hline X2_02 & & $\mathbf{0 , 9 5 5}$ & \\
\hline X2_03 & & $\mathbf{0 , 9 3 6}$ & \\
\hline X2_04 & & $\mathbf{0 , 6 7 3}$ & $\mathbf{0 , 8 9 3}$ \\
\hline Y01 & & & $\mathbf{0 , 9 5 7}$ \\
\hline Y02 & & & $\mathbf{0 , 9 4 9}$ \\
\hline Y03 & & & $\mathbf{0 , 9 7 6}$ \\
\hline Y04 & & & \\
\hline
\end{tabular}

Uji Convergent Validity Penelitian Awal

Berdasarkan table 5.10, terlihat pada indikator variabel literasi keuangan terdapat 3 indikator memiliki loading factor diatas 0,7, yaitu X1_01 (Pengetahuan umum keuangan) sebesar 0,924, X1_02 (Tabungan dan pinjaman) sebesar 0,923 dan X1_04 (Investasi) sebesar 0,943. Sedangkan untuk indikator X1_03 (Asuransi) memiliki loading factor dibawah 0,7 sebesar 0,511. Pada indikator variabel gaya hidup terdapat 3 indikator memiliki loading factor diatas 0,7, yaituX2_01 (Aktivitas) sebesar 0,971, X2_02 (Minat) sebesar 0,955 dan X2_03 (Pandangan seseorang terhadap diri sendiri dan orang lain)sebesar 0,936. Sedangkan untuk indikatorX2_04 (Karakter - karakter dasar) memiliki loading factor dibawah 0,7 sebesar 0,673. Pada indikator variabel perilaku keuangan seluruh indikator memiliki loading factor diatas 0,7, yaituY01 (Membayar tagihan tepat waktu) sebesar 0,893, Y02 (Anggaran pengeluaran) sebesar 0,957, Y03 (Menyiapkan dana tidak terduga) sebesar 0,949 dan Y04 (Membanding kan harga)sebesar 0,976.

\section{Uji Reabilitas}

Uji reabilitas pada penelitian diuji dengan melihat nilai crombach alpha dan composite reability, dimana variabel penelitian akan dinyatakan reliable jika hasil dari kedua nilai tersebut menunjukkan angka lebih dari 0,70 . Berdasarkan hasil pengujian yang dilakukan oleh peneliti, berikut hasil output uji reliabilitas :

\begin{tabular}{|c|c|}
\hline & Composite Reliability \\
\hline Literasi Keuangan (X1) & $\mathbf{0 , 9 6 0}$ \\
\hline Gaya Hidup (X2) & $\mathbf{0 , 9 7 5}$ \\
\hline Perilaku Keuangan (Y) & $\mathbf{0 , 9 7 0}$ \\
\hline
\end{tabular}

Composite Reliability

Hasil uji composite reliability menunjukan bahwa nilai composite reliability variabel literasi keuangan sebesar 0,975 , nilai composite reliability variabel gaya hidup 
sebesar 0,960 , nilai composite realiability variable perilaku keuangan sebesar 0,970 hal ini berarti seluruh variabel dapat dikatakan reliable karena memiliki nilai composite reliability lebih besar dari0,70.

\section{Uji Outer}

\begin{tabular}{cc|} 
& R Square \\
\hline Perilaku Keuangan & $\mathbf{0 , 8 0 0}$ \\
(Y) &
\end{tabular}

R Square Variabel Laten Endogen

Berdasarkan R Square menunjukkan bahwa Perilaku Keuangan mampu dijelaskan oleh Variabel eksogen sebesar 0,800 atau $80 \%$ dan sisanya dijelaskan oleh factor lain diluar model.

\section{Mengkonstruksi Diagram Jalur}

Langkah setelah melakukan perencangan inner model dan outer model selanjutnya dinyatakan dalam bentuk diagram jalur. Bentuk diagram jalur perancangan inner model dan outer model dalam penelitian ini diilustrasikan dalam.

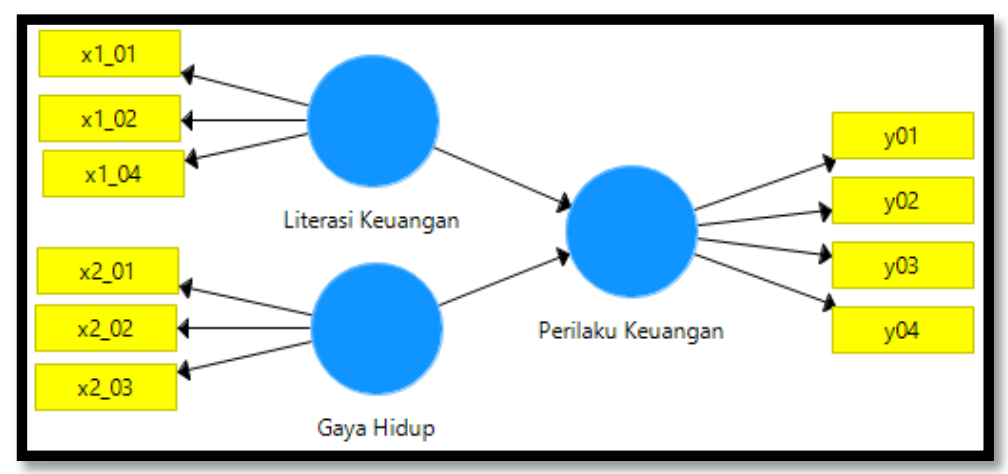

Diagram Jalur Penelitian

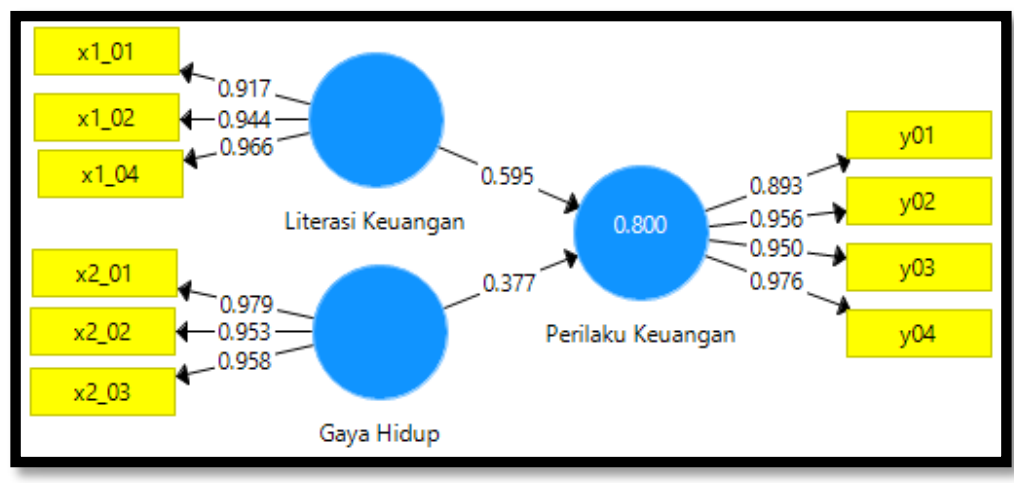

Hasil Perhitungan Model Penelitian

Berdasarkan gambar 5.5 tersebut terlihat bahwa semua indicator telah memiliki nilai loading factor diatas 0,7 .

\section{Estimasi}

Nilai estimasi koefesien jalur antara konstruk harus memiliki nilai yang signifikan. 
Signifikansi hubungan dapatdiperoleh dengan prosedur Bootstapping, Nilai yang dihasilkan berupa nilai t-hitung yang kemudian dibandingkan dengan t-tabel. Apabila nilai t-hitung > t-tabel $(1,96)$ pada taraf signifikansi.

\begin{tabular}{|c|c|c|c|c|c|}
\hline & $\begin{array}{c}\text { Original } \\
\text { Sample }(\mathrm{O})\end{array}$ & $\begin{array}{c}\text { Sample } \\
\text { Mean (M) }\end{array}$ & $\begin{array}{c}\text { Standard } \\
\text { Deviation }\end{array}$ & $\begin{array}{c}\text { T Statistics } \\
(|\mathrm{O} / \mathrm{STDEV}|)\end{array}$ & $\begin{array}{c}\mathrm{P} \\
\text { Values }\end{array}$ \\
\hline $\begin{array}{c}\text { X1 (Literasi } \\
\text { Keuangan) }>\text { Y } \\
\text { (Prilaku Keuangan) }\end{array}$ & $\mathbf{0 , 5 9 5}$ & $\mathbf{0 , 5 8 8}$ & $\mathbf{0 , 0 9 6}$ & $\mathbf{6 , 1 8 0}$ & $\mathbf{0 , 0 0 0}$ \\
\hline $\begin{array}{c}\text { X2 (Gaya Hidup) }>\text { Y } \\
\text { (Prilaku Keuangan) }\end{array}$ & $\mathbf{0 , 3 7 7}$ & $\mathbf{0 , 3 8 3}$ & $\mathbf{0 , 1 0 8}$ & $\mathbf{3 , 4 8 2}$ & $\mathbf{0 , 0 0 1}$ \\
\hline
\end{tabular}

Estimasi

Wiyono (2011), estimasi koefesien jalur antara konstruk harus memiliki nilai yang signifikan. Signifikan sihubungan dapat diperoleh dengan prosedur Bootstapping, Nilai yang dihasilkan berupa nilai t-hitung yang kemudian dibandingkan dengan t-tabel. Apabila nilai t-hitung > t-tabel $(1,96)$ Maka nilai estimasi koefesien jalur tersebut signifikan. Berdasarkan Tabel 5.12 untuk Literasi Keuangan terhadap Perilaku Keuangan t-hitung 6,180> t-tabel 1,96 yang berarti terdapat pengaruh signifikan antara variabel Literasi Keuangan terhadap Perilaku Keuangan. Untuk variabel Gaya Hidup terhadap Perilaku Keuangan t-hitung 3,482 > t-tabel 1,96 yang berarti terdapat pengaruh signifikan antara variabel Gaya Hidup terhadap Perilaku Keuangan.

\section{Pembahasan}

Literasi Keuangan Berpengaruh Signifikan Terhadap Perilaku Keuangan karyawan Pertambangan Batu Bara Di Kabupaten Sarolangun (PT. MBS)

Berdasarkan hasil uji hipotesis disimpulkan bahwa literasi keuangan mempunyai pengaruh signifikan terhadap perilaku keuangan. Berdasarkan Tabel 5.18 menunjukkan bahwa pengaruh literasi keuangan terhadap perilaku keuangan signifikan dengan t-stat sebesar 6,180.

Gaya Hidup Berpengaruh Signifikan Terhadap Perilaku Keuangan karyawan Pertambangan Batu Bara Di Kabupaten Sarolangun (PT. MBS)

Berdasarkan hasil uji hipotesis disimpulkan bahwa gaya hidup mempunyai pengaruh signifikan terhadap perilaku keuangan. Berdasarkan Tabel 5.18 menunjukkan bahwa pengaruh gaya hidup terhadap perilaku keuangan signifikan dengan t-stat sebesar3,482.

Selain literasi keuangan, gaya hidup seseorang juga mempengaruhi perilaku keuangan seseorang. Berpengaruhnya gaya hidup terhadap perilaku keuangan dikarenakan kebutuhan akan gengsi dan prestisie membuat seseorang menjadi lupa akan konsep keinginan dan kebutuhan dalam melakukan pembelian.

Literasi Keuangan Dan Gaya Hidup Berpengaruh Signifikan Terhadap Perilaku Keuangan karyawan Pertambangan Batu Bara Di Kabupaten Sarolangun (PT. MBS) 
Berdasarkan hasil uji hipotesis disimpulkan bahwa literasi keuangan dan gaya hidup secara simultan mempunyai pengaruh signifikan terhadap perilaku keuangan. Berdasarkan uji $\mathrm{F}$ statistic menunjukkan bahwa pengaruh literasi keuangan dan gaya hidup secara simultan terhadap perilaku keuangan signifikan dengan F-stat sebesar 104. Literasi keuangan dan gaya hidup memiliki pengaruh yang signifikan secara simultan terhadap perilaku keuangan, dikarenakan pemahaman seseorang tentang manajemen keuangan saja tidak cukup untuk memiliki perilaku keuangan yang sehat. Hal ini disebabkan kebutuhan seeseorang akan gaya hidup akan membuat ia mengabaikan setiap pemahamannya tentang manajemen keuangan. Pemahaman seseorang tentang manajemen keuangan harus dibarengi dengan gaya hidup yang sederhana, diaman ia mampu mengidentifikasikan antara kebutuhan dan keinginannya.

\section{SIMPULAN DAN SARAN}

\section{Simpulan}

1. Literasi keuangan secara parsial memiliki pengaruh yang signifikan terhadap perilaku keuangan.

2. Gaya hidup secara parsial memiliki pengaruh yang signifikan terhadap perilaku keuangan.

3. Literasi keuangan dan gaya hidup secara simultan mempunyai pengaruh yang signifikan terhadap perilaku keuangan.

\section{Saran}

Setelah melakukan penelitian, peneliti sadar bahwa beberapa aspek dalam penelitian masih belum sempurna. Saran Bagi Karyawan Pertambangan Batu Bara di Kabupaten Sarolangun merujuk dari hasil penelitian yang menyimpukan literasi keuangan dan gaya hidup mempengaruhi perilaku keuangan, oleh karena itu diharapkan bagi karyawan pertambangan batu bara di Kabupaten Sarolangun utnuk dapat meningkatkan kemampuan literasi keuangan serta menggunakan gaya hidup sederhana untuk mencapai perilaku keuangan yang baik sehingga karyawan tersebut dapat memenuhi setiap kebutuhan yang diperlukan. Bagi akademisi diharapkan agar dapat memperluas objek penelitian tidak hanya pada pertambangan batu bara di Kabupaten Sarolangun saja, namun perusahaan dikabupaten lain. Selain itu, penelitian selanjutnya diharapkan agar dapat meneliti variabel lain terkait perilaku keuangan.

\section{Daftar Pustaka}

Ghozali, imam. (2011). Aplikasi Analisis Multivariate Dengan Program PLS. Badan Penerbit Universitas Diponegoro.Semarang.

Lusardi, A., \& Mitchell, O. S. (2012). Financial Literacy Around The World:An Overview. Journal of Pension Economics and Finance, 10 (4): 497- 508.

Lusardi, A., \& Mitchell, O. S. (2011). Financial literacy around the world: An overview. Journal of Pension Economics and Finance, 10(4), 497-508. https://doi.org/10.1017/S1474747211000448

Mendari, A. S. dan S. S. K. 2013. Tingkat Literasi Keuangan Di Kalangan Mahasiswa STIE Musi,Jurnal Economia, 9 (2): 130-140.

Mowen, John C dan Minor, M. (2012). Perilaku Konsumen Dialih Bahasakan Oleh Dwi Kartika Yahya. Jakarta : Erlangga.

Nababan, D., \& Sadalia, I. (2012). Analisis Personal Financial Liteacy dan Financial 
Behavior Mahasiswa Strata I Fakultas Ekonomi Universitas Sumatera Utara. Media Informasi Manajemen, 1(1), 1-16.

Nofsinger, J. R. . 2001. Investment Madness: How Psychology Affects You Investing and What to Do About It. Prentice Hall.

Otoritas Jasa Keuangan (2013). In Buku Seri Literasi Keuagan, diunggah Dari http://jurnal.usu.ac.id/index.php.jmim.article/view.651.

Parmitasari, R. D. A., Hamsah, D., Alam, S., \& Laba, A. R. (2018). Analysis of Ethics and Investor Behavior and Its Impact on Financial Satisfaction of Capital Market Investors. Scientific Research Journal, VI(I), 51-69. http://www.scirj.org/jan-2018paper.php?rp=P0118488

Putri, I. A. (2020). Perilaku Keuangan dalam Pengambilan Keputusan Berinvestasi Properti Apartemen di Surabaya. Finesta, 3(1), 1-6.

Ricciardi, V., \& Simon, H. K. (2011). What Is Behavivoral Finance?.Business, Education and Technology Journal.USA.

Ridwan S. Sundjaja, Budiana G., Dharma P. Sundjaja., dkk. 2011. "Pola Gaya Hidup Dalam Keuangan Keluarga". Bina Ekonomi Majalah Ilmiah Fakultas Ekonomi Unpar.Vol. 15.No. 2.Hal. 16-31.

Rina Rahayu, A. A. (2015). PENGARUH PENDIDIKAN, LINGKUNGAN KELUARGA, PERGAULAN DAN GAYA HIDUP TERHADAP PERILAKU PENYIMPANGAN KERJA dan KEUANGAN. Ilmu Manajemen Magistra, 1(1), 1-15.

Suryanto.(2017). (n.d.). No Title. Pola Prilaku Keuangan Mahasiswa Di Perguruan Tinggi.Jurnal Ilmu Politik Dan Komunikasi,VII(1), 11-20.

Suryanto. (2017). Pola Perilaku Keuangan Mahasiswa Di Perguruan Tinggi. Jurnal Ilmu Politik Dan Komunikasi, VII(1), 11-20.

SUpadana, I. W. Y. A., \& Herawati, N. T. (2020). Pengaruh Literasi Keuangan dan Perilaku Keuangan terhadap Keputusan Investasi Mahasiswa. Jurnal Ilmiah Akuntansi Dan Humanika, 10(2), 126. https://doi.org/10.23887/jiah.v10i2.25574 